\title{
Demographic data and barriers to professionalisation in playwork
}

\section{Word Count: 6732}

\begin{abstract}
Playwork is an emerging profession and little is known about the demographics of the playwork sector. The lack of demographic data has hampered the development of the professionalisation of the playwork field, as playworkers have been unable to substantiate claims about the extent and impact of their field with sufficient reliable evidence. As part of an online survey undertaken to explore playworker's understanding of the Play Cycle theory (King and Newstead, 2019), playworkers were asked to provide background demographic data on years of practice, job role, qualification and location. This created a data set with which to explore possible relationships between these four factors using Pearsons Chi Squared analysis. The results indicated that there are potential relationships between playwork practice with firstly years of practice and secondly with highest playwork qualifications. Perhaps more significantly, this study highlights some of the key challenges in collecting and analysing demographic data in the playwork field and offers some potential solutions which, although imperfect, could be built upon in further studies to produce demographic data with which to inform the he professionalisation of the playwork field.
\end{abstract}

Key Words: Playwork; Playwork Education; Playwork Training; Playwork Qualifications; Playwork Profession

\section{Introduction}

Playwork evolved out of the adventure playground movement in the 1950s and 1960s (King and Newstead, 2017) and is currently one of the seven skills sectors within SkillsActive, the Sector Skills Council for the Active Leisure, Learning and Well-being sector (SkillsActive, 2010a). SkillsActive is an independent UK employer-led organisation licenced by the Government to develop skills to meet employer needs (SkillsActive, 2010a, 3) and defines playwork as: 
A highly skilled profession that enriches and enhances provision for children’s play. It takes place where adults support children's play, but it is not driven by prescribed education or care outcomes

However, the journey from a community of practice (Wenger-Trayner \& Wenger-Trayner, 2015) to a 'profession' has been anything but smooth. The question of professional identity has perplexed the playwork field for the last seven decades (Kershaw, 1985; Joint National Committee on Training for Playwork (JNCTP), 1997). The playwork field has invented and reinvented itself from a handful of committed but untrained adventure playground pioneers sharing their experience about their work in order to better understand it, into a disparate array of adults working with (largely) school-aged children in a wide range of out of school settings, including out of school clubs, holiday playschemes, open access in parks and open spaces, within hospitals and within prisons (Newstead, 2016). According to Banks (2010) four characteristics of a profession (training; code of ethics; professional associations and recognition in law), the playwork field has made some advances in securing professional status but is still lacking in others. Playwork has its own vocational qualifications (Bonel \& Lindon, 1996) and there has been some work undertaken in the area of professional ethics (JNCTP), 2006, Stonehouse, 2015). In recent years there has also been a growing interest in the study of playwork. Playwork courses have been offered at various Further Education (FE) and Higher Education (HE) institutions across the UK, including Foundation Degrees, three year undergraduate courses, research degrees at Masters levels and playwork practitioners undertaking research at doctoral level (Dallal, 2015; King and Newstead, 2017). Despite these advances, the playwork field still lacks one of the key features of a profession: a professional association or regulatory body. Since the early days of the adventure playgrounds, playworkers have repeatedly complained that their voices are not heard or valued as a valid alternative approach to working with children, but several attempts to establish a professional body to represent the collective views of those working in the playwork field have been tried and failed (Allen, 1953, Fewtrell, 1987). 
This lack of a professional body for playworkers means that there is no single officially recognised and standardised definition of the terms 'playwork' and 'playworker'. Whilst the Playwork Principles No. 5 state that "the role of the playworker is to support all children and young people in the creation of a space in which they can play” (PPSG, 2005), in the playwork field there are currently several different competing definitions of about what playwork is and what it is for (Conway, Hughes and Sturrock, 2004, King \& Sturrock, 2019). Numerous attempts over the last forty years to articulate playwork, and the aim and role of those who do it have created plenty of disagreements as to the nature of "true playwork" (Else, 1997), which has resulted in schisms amongst those who describe themselves as playworkers (PlayEducation, 1983; Benjamin and Welsh, 1992). In the absence of any widely recognised definition of playwork or playworker, further definitions of playwork have also been developed by those outside the playwork sector, with playwork often being conflated with other sectors within the children's workforce, such as childcare and extended education (Leach, 2009). This lack of a standard definition of playwork creates significant limitations for the collection of meaningful demographic data about the playwork field, as it hinders accurate or meaningful operationalisation of terms such as 'playwork' and 'playworker. Despite the playwork field's established history and semi-professional status, currently anybody can call themselves a 'playworker' irrespective of their job role and level and type (if any) of qualification.

Claims about the value or validity of playwork as a profession need to be substantiated by meaningful and robust demographic data which demonstrates that playwork is a collective alternative approach to working with children, rather than the coincidental practices of a handful of like-minded people. Establishing meaningful and robust demographic data is a key issue in operationalisation. In recent years there have been several attempts to estimate the number of people in the playwork sector, yet these figures are flawed by the lack of a robustly constructed operationalisation of playwork. For example, in 2003, it was estimated that there were 275,000 paid staff in the childcare and playwork sector (Rolfe, Metcalf and Meadows, 2003) whilst a survey by SkillsActive (2010a) estimated that there were around 146,700 playworkers in the United Kingdom, with approximately 7,100 in Wales (SkillsActive 2010b), and 12,100 in Scotland (SkillsActive, 2010c). However, these figures are based 
on an estimate which included those working in playgroups (i.e. with under-5's) and therefore cannot be said to portray an accurate picture of the numbers of those working in playwork settings, as playwork is generally associated with working with school age children (SkillsActive, 2011). In addition, how many workers in these samples would consider themselves to be playworkers rather than childcare workers is highly debateable. Perhaps a more reliable figure might be found in the last UK census, where 52, 429 respondents stated that they were 'playworkers' by trade, although only 32,754 reported themselves to be employed as such (Office for National Statistics (ONS), 2011). However, one of the difficulties with this census data is that it is unclear on what basis respondents defined their role as a playworker, or which of the many iterations of playwork they adhered to.

Alternative approaches to operationalising the term 'playworker' were therefore explored for the purposes of this study. One approach to operationalising the term 'playworker' might be to define playworkers as those with playwork qualifications. Within the playwork field, there are currently two recognised levels of qualifications: vocational, based on the National Occupational Standards for Playwork (NOS) e.g. SkillsActive, 2017), and higher education. However, there are two difficulties with defining a playworker as somebody who holds a playwork qualification. Firstly, the playwork NOS have been heavily criticised within the playwork field for not accurately reflecting the role of the playworker and for conflating playwork with childcare (see for example, Milne, 1998; Wood, 2006). It is therefore highly debateable whether holding a playwork qualification can be said to truly reflect whether somebody is 'doing playwork', or, given the number of variations on the theme of playwork as mentioned above, which variety of playwork they are doing. Secondly, as this study and other literature confirms, not everybody who describes themselves as a playworker holds playwork qualifications (SkillsActive, 2010b). To count playworkers simply as those who hold playwork qualifications therefore runs the risk of excluding a significant sample of experienced playwork practitioners, trainers, theorists and academic lecturers and researchers.

Another approach to defining who or what is a playworker might be to ask those who call themselves playworkers to state whether they work according to the Playwork Principles, which underpin the 
National Occupational Standards for Playwork (PPSG), 2005). The Playwork Principles were developed by the playwork field and attempt to set out "a fundamental and ethical framework describing the unique playwork perspective” (PPSG 2005, 1). However, using the Playwork Principles for the purposes of defining who is a playworker is also unreliable, as, according to SkillsActive (2007), only half of the playwork workforce have heard of them. Furthermore, no data is available as to how many playworkers actually use the Playwork Principles to guide their practice. The Playwork Principles have also been critiqued by those working in playwork as being unrepresentative of the true aims and objectives of the field (Brown, 2008), raising the question of the validity of using the Playwork Principles as a defining feature of playwork.

It is in this fluid field of definitions and variations on the theme of playwork that a broader study on playworker’s understanding of the Play Cycle (Sturrock and Else, 1998) theory was undertaken (King and Newstead, 2019) which involved demographic data of job role, qualifications, years of practice and location. This paper reports on how potential relationships between playwork job roles, playwork experience and playwork-specific training and qualifications were explored from the demographic data collected as part of this larger study. It should be stated from the outset that neither the original study nor the present one set out to address the significant question of the operationalisation of playwork as a field or a profession, but instead relied on a self-selecting sample of adults working with children who described themselves as playworkers. (It should be noted that, for ease of reading, the term 'playworker' is used as shorthand throughout this paper to mean 'adults working with children who describe themselves as playworkers', rather than referring to any particular definition of playwork or the playwork role.) On that level it therefore should be recognised that this study is as flawed as previous studies which have involved self-selecting samples, for all the reasons stated above. However, the playwork field has traditionally treated quantitative research methods with suspicion, eschewing notions of measurement in favour of narrative methods of describing and explaining playwork (see for example PLAYLINK, 1998; Lester and Russell, 2004). One of the arguments advanced against the use of quantitative methods in playwork is that they are prescriptive and therefore result in prescriptive playwork practices or outcomes (Russell, Lester and Smith, 2017). 
This paper demonstrates how challenges in the professionalisation of playwork which have vexed the playwork field for the last seventy years can be explored and advanced through the use of statistical data. It also identifies how further studies could build on this methodology to collect more demographic data with which to inform the professionalisation of playwork.

\section{Method}

This study was granted ethical approval by the ethics committee within the College of Human and Health Science at Swansea University. The online survey addressed the important aspects of informed consent of non-coercion, voluntary participation, confidentiality, anonymity and right to withdraw before the online survey was submitted. Once the online survey was submitted, all information was used.

The online survey was made available between September and December 2017 and was circulated through a range of methods that included data bases, local and national playwork networks and social media. The online survey can be divided into three main components:

1. Demographics: current playwork practice; years of service and level of qualification

2. Understanding of the Play Cycle: how playworkers were introduced to the Play Cycle and their current understanding of the components of the Play Cycle (meta-lude; play cue; play return; play frame; loop and flow and annihilation)

3. Potential Influence of the Play Cycle: this included the adult role in the Play Cycle and if the theory has influenced playwork practice

This paper is only focused on the demographics looking at current playwork role, years of service, playwork location and level of qualification. For more information on the research of playworker's understanding of the Play Cycle see King and Newstead (2019) and King and Sturrock (2019). 
Playworkers were asked to provide the following demographic data by stating (see King and Newstead cited in King and Sturrock, 2019):

- How many years they had worked in playwork with options of less than 1 year, 1 year, 2 years in annual increments up to $11+$ years.

- Their main current role from Playwork Practitioner, Playwork Trainer, Development Officer, Manager, FE lecturer, HE lecturer, Student and Volunteer (allowing for the possibility of someone having more than one playwork role).

- Their highest playwork qualification with options of no playwork qualification; level 2, level 3, level 4, undergraduate degree, postgraduate degree and $\mathrm{PhD}$.

- Where most of their playwork practice was undertaken with options of England, Wales, Scotland, Northern Ireland, Republic of Ireland and outside the UK.

With the lack of responses from Northern Ireland, Republic of Ireland and Rest of the World, it was decided for this demographic study to focus only on the responses from England, Scotland and Wales. It was deemed that the low number responses would not be a fair reflection of playwork outside of Great Britain. This resulted in a sample size of 137 (from the 157 total sample size).

The data collected from the online survey for playwork practice and highest playwork qualification are nominal type data. Nominal type data is assigned to groups or categories and thus analysis is often limited to descriptive statistics. However, it is possible to use Chi Square statistical analysis to hypothesis potential relationships between nominal categories. The following hypothesis were considered for this study:

H1: There is a relationship between years of practice and current playwork role

H1: There is a relationship between years of practice and highest playwork qualification 
H1: There is relationship between current playwork role and highest playwork qualification

H1: There is a relationship between location of playwork practice and highest playwork qualification

Possible relationships between any of these variables might to provide meaningful data which identifies key characteristics of the playwork workforce and thus begin to move the playwork field from a well-meaning community of practice to a distinct body of professional practitioners.

\section{Descriptive Statistics}

Initial analysis of the demographic data showed for years of playwork practice, two population curves were identified: 0-7 years and 8+ years (see King and Sturrock, 2019). The different playwork roles were collapsed into three groups: playwork practitioner; playwork educator and playwork management and development in order to create large enough group to undertake statistical analysis. With respect to highest playwork related qualification, three groups were produced: no playwork qualification, up to level 3 and level 4-8. A summary of the descriptive statistics is shown below:

- $17 \%$ of playworkers have been working $0-7$ years $(n=23)$ and $83 \%$ working $8-11+$ years $(n-$ 114). Most playworkers completing this online survey clearly have $11+$ years of playwork practice.

1. $29 \%$ were playwork practitioners $(n=40), 19 \%$ were playwork educators (26) and $52 \%$ were playwork management and development $(\mathrm{n}=71)$

2. $15 \%$ had no playwork qualification (n=17), $38 \%$ had up to level 3 qualification ( $n=42)$ and 47\% had up between level 4 and level 8 ( $n=52)$.

3. $69 \%$ worked and studied playwork in England $(n=94), 18 \%$ from Wales $(n=24), 14 \%$ from Scotland ( $\mathrm{n}=19)$. 
The advantage of combining variables into smaller groups (0-7 years and 8+years, playwork practitioner, educator and management/development, no playwork qualification, up to level 3 and level 4-8) is that it enables a better chance to carry out a Pearson's Chi Square for association (Ugoni and Walker, 1995).

The Pearson's Chi Square test for association tests for independence of two nominal (categorical) variables or whether there is a pattern of dependence between them. A series of Chi Square tests were undertaken to test for possible relationships between years working in playwork, current playwork role, highest playwork qualification, and location of playwork practice. For each Pearson’s Chi Square test for association, a Cramer V test was also undertaken to find out effect size where a value of up to 0.2 is a small effect, 0.3 is a medium effect and 0.5 and above is a large effect. In addition, post-hoc adjusted residue analysis was also undertaken. Residue analysis "identifies those specific cells making the greatest contribution to the chi-square test result" (Sharpe, 2015, 2) where "A residual is the difference between the observed and expected values for a cell. The larger the residual, the greater the contribution of the cell to the magnitude of the resulting Chi-Square obtained value” (Sharpe, 2015, 2). A residual value above 2.0 or below -2.0 indicated which nominal (categorical) variables have the strongest relationship.

Chi Square analysis for years of practice and current playwork role, years of practice and highest playwork qualification and current practice and highest playwork qualification.

The final set of nominal variables related to location for England, Wales or Scotland.

\section{Results}

Chi Square analysis found two significant relationships only. The first was between years of playwork practice and main playwork role.

[Insert Table 1 Here] 
There is a significant relationship between years in playwork and main role in playwork $x^{2}(2, N=$ $137)=11.04, \mathrm{p}<0.004$. Post-hoc analysis indicates that playworkers working between $0-7$ years are more likely to be a practitioner (adjusted residue 3.2) and playworkers with $8+$ years playwork experience are more likely to be an educator (adjusted residue 3.2). Cramers V is 0.284 which has a medium size effect. Although one observed count is below 5 (teaching and $-0-7$ years), this is less than $20 \%$ so does not violate the Chi Square analysis.

The second relationship was between years of playwork practice and highest playwork qualification. The is shown in Table 2.

[Insert Table 2 Here]

There is a significant relationship between years in playwork and highest playwork qualification $\mathrm{x}^{2}(2$, $\mathrm{N}=111)=6.19, \mathrm{p}<0.045$. Cramers $\mathrm{V}$ is 0.237 and has a medium size effect. A post-hoc standardised test shows that those working in playwork between 0-7 years are more likely to have no playwork qualification (advanced residue 2.4), whereas playworkers with $8+$ years playwork experience are less likely to have no qualification (advanced residue -2.4). Table 2 also shows that a playwork educator is less likely to have a playwork qualification up to level 3 but more likely to have a qualification between 4-8, whilst playwork managers and development officers are more likely to have a playwork qualification up to level 3.

The results from the Pearson's Chi Square test for association identified a relationship between years of practice and current playwork role and a relationship between years of practice and highest playwork qualification. This playwork demographic data has implications for the development of playwork as a profession, particularly in the area of playwork education and training. 


\section{Discussion}

The findings indicate that there is a potential relationship between current playwork role and years of playwork practice where more playwork practitioners were found to be working 0-7 years without any playwork qualifications. Playworkers with $8+$ playwork experience are more likely to hold a playwork qualification and more likely to be an educator. Whilst these findings may appear on the surface to be relatively modest, within the context of an emerging profession such as playwork which currently has no demographic about its workforce, these findings raise some important questions about the development of the playwork profession and highlight areas for further research.

Perhaps somewhat paradoxically for a sector which has traditionally shunned data in favour of narrative 'evidence' for its existence, the data produced by this study appears to confirm what has been believed to be the case in the playwork field for a long time: that experience is important (Nicholson, 1954). 'Hands on' experience (that is, experience of doing playwork directly with children) has always been highly valued as an indicator of being able to fully understand the true nature and purpose of playwork and of being able to deliver high quality playwork when working with children. By extension, managers and educators without significant or current playwork experience are often treated with suspicion, as their understanding of what it means to put playwork into practice is regarded as limited by their lack of practical experience (Wood, 2003). The data collected in this study appears to indicate that only those with substantial hands on playwork experience (more than seven years) become playwork educators, which may confirm the generallyheld playwork assumption that playwork experience is a pre-requisite for good quality playwork. Further research on a larger scale needs to be carried out to establish whether this is the case.

However, further research should investigate why playwork experience is an indicative factor in good quality playwork and also whether playwork experience makes a difference to the quality of training and education in the playwork sector. It is commonly believed in the playwork sector that a lack of practical experience and playwork-specific knowledge in playwork educators is one of the most significant factors in the creation of different understandings of the nature and purpose of playwork 
(Else, 1997). However, the data collected in this study indicates that the level of qualifications could also play a role in developing understandings of good quality playwork. According to this data, playwork educators are more likely to be more highly qualified than playwork practitioners or managers. This would suggest that playwork educators have more playwork experience on which to base their knowledge of professional practice and should also possess a greater understanding of the knowledge which underpins the playwork profession due to their increased levels of study.

Training in the playwork field, a key feature of professions (Banks, 2010), has been heavily informed by the development of playwork theory, such as Hughes’ (2002) Play Types and Sturrock and Else’s Play Cycle. The original research on playworker's understanding of the Play Cycle theory found that playworker's understanding of some elements of the Play Cycle theory varied with years of playwork practice and playwork qualifications (King and Newstead, 2019). This could suggest that playwork educators have different understandings of this central playwork theory regardless of their substantial years of practical experience and higher qualifications and are therefore teaching different understandings to those working at grass roots level. If training of key playwork theories is inconsistent and depends on the experience of the trainer, the professionalisation of the playwork field could be undermined by potential variation in playwork knowledge across the workforce. Further research is required to explore the respective roles of playwork experience and playwork qualifications in developing a sound and unique theoretical basis for playwork. This might include further studies on the Play Cycle theory, building on the existing work in this area, or examining how other key playwork theories are understood by those working in the playwork field.

This neglected area of the development and transmission of playwork knowledge raises potential concerns for the future development of the professionalisation of playwork, as theory underpins professional practice and discrete professions are defined by their own unique knowledge base (Eraut, 2003). A discrete knowledge base for playwork is crucial to the development of playwork as a recognised and valued profession, and yet is one which to date has barely discussed in the playwork literature. Instead, the playwork field has relied on experience to develop and define its unique 
approach to working with children rather than theory (Battram, 2003). However, experience alone cannot create robust theory, and without a strong theoretical foundation the playwork field will struggle to develop its own distinct knowledge base with which to distinguish itself from other professions. In the move from community of practice to full-blown professionalism, there is a need for the playwork field to pay serious attention to what constitutes playwork knowledge and how it is delivered to ensure a consistency of understanding which could be described as a basis for professional practice.

Another key issue of potential concern highlighted by the data set is how experienced playworkers pass on playwork-specific knowledge to less experienced playworkers. The demographic data in this study indicates that after $8+$ years of playwork experience, practitioners take on more management and development responsibilities, which often includes the recruitment and support for new playworkers. Part of this role will include passing on information about the nature and purpose of playwork to less experienced playworkers. In the current era of austerity in the UK, playwork qualifications and Higher Education courses have been cut, rendering playworkers increasingly reliant on local and in-house training (King and Newstead, 2019). If playworkers with 0-7 years playwork practice are not undertaking professional qualifications, this could indicate that their playwork understanding and knowledge is being 'passed down' through work settings, making them reliant on their managers' interpretations of what playwork is and what it is for. This raises further questions about defining playwork as a unique profession and whether the variations in understandings passed down from experienced to less experienced playworkers will further diversify the already fragmented playwork sector. The data from this study suggests that a drop in the uptake of playwork qualifications and more localised and 'on the job' training may result in further inconsistencies in understandings which could make it more likely that the future playwork field will still be unable to agree on the nature and purpose of playwork or what constitutes specific playwork knowledge. This would mean that the long-cherished playwork vision of achieving a distinct playwork identity with its own professional body to raise its collective voice is as unachievable in the next seventy years as it has been in the last seventy. 
In many ways this paper has only been successful in rehearsing the circular forays into the complexities of developing a new profession which have already been debated in the playwork field over the last seventy years. An initial statistical attempt to understand potential relationships between playworker's job role, years of experience and qualifications has resulted in the possible confirmation of what playworkers believe they already know: that there is a relationship between playwork experience and job role. However, in exploring the implications of this relationship, this paper has also highlighted questions which the playwork field has been unable to answer for the last seventy years, such as what is a playworker? (JNCTP, 1997); what is the role of theory in playwork? (Newman, 2003); is playwork experience more important in developing good quality playwork than playwork qualifications? (Potter, 2003); what is playwork knowledge and how should this be taught? (Melville, 1998); who trains the trainers? (Abernethy, 1975); who regulates practitioners? (Kershaw, 1985); what distinguishes playwork from other approaches to working with children? (Davy, 2007). And perhaps most importantly, how to define the nature and purpose of playwork? (Kingston, 2008). Perhaps what this study has demonstrated more than anything else is the need for the playwork field to focus whatever collective effort it can muster on developing answers to these questions to progress the professionalisation of playwork. For until the playwork field can collectively and coherently reach its own (robust) conclusions about the extent and validity of its work, others will be free to draw their own.

\section{Conclusion}

This paper has discussed some of the key challenges in both collecting demographic data and using data to support the professionalisation of playwork. The analysis of the demographic data showed a relationship between current playwork role and years of playwork practice and playwork qualifications, which presents challenges for the professionalisation of the playwork field. Rather 
than presenting solutions to age-old questions, this paper has demonstrated that statistical data could play an important part in helping the playwork sector to define not only its foundations, but also itself. Further studies could build on the methodology used in this study and also further explore the barriers identified to the collection of numerical data with which to inform the professionalisation of playwork.

\section{References}

Abernethy, W. D. 1975. Training of Workers for Adventure Play. Adventure Playground in Theory and Practice conference. Adventure Playgrounds and Children's Playgrounds; Report of the Sixth International Conference. University Bucconi, Milan, Italy, IPA International Playgrounds Association. Allen, Lady Allen of Hurtwood (1953). Proposed Organisation for Initiating Adventure Playgrounds. Modern Records Centre, University of Warwick

Battram, A. (2003). Stop that George! ....the key to effective playwork is theory not practice.

Playwords. Eastleigh, Common Threads Publications Ltd

Benjamin, J. and R. Welsh 1992. "Play and Participation". Streetwise, 12, 2-8.

Bonel, P. and J. Lindon 1998. Good Practice in Playwork. Cheltenham: Stanley Thornes (Publishers) Ltd.

Brown, F. 2008. The Playwork Principles: a critique. In Foundations of Playwork edited by F. Brown, and C. Taylor, 123-127. Maidenhead: Open University Press.

Conway, M., B. Hughes and G. Sturrock 2004. A New Playwork Perspective accessed at http://www.fairplayforchildren.org/pdf/1308498073.pdf.

Dallal, J. 2015) "quest to professionalise playwork through higher education". Journal of Playwork Practice, 2(1), 71-75. 
Davy, A. 2007. Playwork: Art, Science, Political Movement or Religion? In Playwork Voices: In Celebration of Bob Hughes and Gordon Sturrock edited by W. Russell, B. Handscomb and J. Fitzpatrick. London, London Centre for Playwork Education and Training. Else, P. (1997). Managing Personal Behaviour - a View of Reflective Playwork. In Therapeutic Playwork Reader one 1995-2000 edited by P. Else and G. Sturrock, 39-46. Eastleigh: Common Threads Publications Ltd.

Eraut, M. (2003). "The many meanings of theory and practice". Learning in Health and Social Care, 2, 61-65.

Fewtrell, J. 1987. "PlayBoard Liquidation". Schools Out. London, Kids Clubs Network. Joint National Committee on Training for Playwork (1997). What's A Playworker Then? JNCTP Joint National Committee on Training for Playwork (2006). An Ethical Code for Playworkers. JNCTP Kershaw, D. T. 1985. The need for a professional institute. PlayEd 1985 - The Priorities - Issues in Context. PlayEducation.

King, P. and S. Newstead 2017. Researching Play from a Playwork Perspective. London: Routledge. King, P. and S. Newstead 2017. Introduction. In Researching Play from a Playwork Perspective edited by P. King and S. Newstead, 1-7. London: Routledge.

King, P. and S. Newstead 2019. "Re-defining the Play Cycle - an empirical study on playworker's understanding of playwork theory". Journal of Early Childhood Research. 18 (1): 99-111. King, P. and G. Sturrock 2019. The Play Cycle: Theory, Research and Application. London: Routledge Kingston, B. (2008). Playwork - Mostly harmless? - Ideas Paper 13. Possible Futures for Playwork. London, Play England.

Leach, P. 2009. Childcare Today: What we know and what we need to know, Oxford: Policy Press. Lester, S. and W. Russell 2004. Towards a curriculum for advanced playwork practice: Background and context for the proposal. In Playwork Qualifications Raising the Standard A Report of the JNCTP 
EQUIPE Project 2003 to 2005 edited by H. Hunter and J. Martin. London: JNCTP Joint National Committee on Training for Playwork.

Milne, J. (1998). "Conflict of Terminology - definitions of playwork and childcare". Playwords 1, 12.

Newman, A. (2003). An exploration of the relationship between playwork theory and practice. Leeds: Leeds Metropolitan University.

Newstead, S. 2016. Deconstructing and reconstructing the unorthodox recipe of playwork.

Unpublished doctoral thesis, UCL Institute of Education, London, UK.

Nicholson, M. (1954) Notes on Adventure Playgrounds. London: National Playing Fields Association. Palmer, M., P. Wilson and A. Battram 2007. The Playing That Runs Through Us Al: Illustrating the Playwork Principles with Stories of Play. In Playwork Voices: In celebration of Bob Hughes and Gordon Sturrock edited by W. Russell, B. Handscombe and J. Fitzpatrick. London: London Centre for Playwork Education and Training.

PlayEduation (1983). PlayEd 1983 - Play and Playwork: Developments and Definitions. In PlayEducation edited by Bob Hughes. Bolton, PlayEducation.

PLAYLINK and Portsmouth City Council. (1998). Measure or Value - Exploring outcomes from play provision. Conference Proceedings of the Joint PLAYLINK/Portsmouth City Council Conference. Play Principles Scrutiny Group (PPSG, 2005). The Playwork Principles accessed at http://www.skillsactive.com/PDF/sectors/Playwork Principles.pdf

Rolfe, H., Metcalfe, H., Anderson, T. and Meadows, P. 2003. Recruitment and retention of childcare, early years and play workers: research study, London: National Institute of Economics and Social Research.

Potter, D. (2003). Whatever happened to.... Play Times.

Russell, W., S. Lester, and H. Smith 2017. Practice-based Research in Children's Play. Policy Press, Bristol.

Sharpe, D (2015). "Your Chi-Square Test is Statistically Significant: Now What?" Practical Assessment, Research \& Evaluation, 20(8). Available online: http://pareonline.net/getvn.asp?v=20\&n=8 
SkillsActive (2007). Playwork people 3: research into the characteristics of the playwork workforce (Government document). London: SkillsActive.

SkillsActive (2010a). AACS LMI Factsheet. London: SkillsActive.

https://warwick.ac.uk/fac/soc/ier/ngrf/Imifuturetrends/sectorscovered/sportandleisure/links/skills active Imi - march 2010.pdf

SkillsActive (2010b). Sector Skills Assessment Active Leisure, Learning and Well-being Wales Summary. London: SkillsActive.

SkillsActive (2010c). Sector Skills Assessment Active Leisure, Learning and Well-being Scotland. London: SkillsActive.

SkillsActive (2011). Sector Skills Assessment 2011 UK Summary Report (Government document). London: SkillsActive.

SkillsActive (2017). List of Required Qualifications to work within the Playwork Sector in Wales Available online https://www.skillsactive.com/PDF/List_of_Required_Qualifications_May_2017.pdf. Stonehouse, D. 2015. Ethical practice for the playwork practitioner. International Journal of Play, 4, 314-323.

Sturrock, G. and Else, P. (1998). 'The Colorado Paper' - The playground as therapeutic space:

Playwork as healing. In Therapeutic playwork reader one 1995-2000 edited by P. Else \& G. Sturrock, 73-104. Eastleigh: Common Threads Publications Ltd.

ONS Office for National Statistics (2011). Statistical data from 2011 UK national census - playworkers (Government document). London.

Ugoni, A. and B. F. Walker 1995. "The Chi square test: an introduction". Comsig Review, 4(3), 61-64. Wood, A. (2003) The playwork assessor training pack. Revised. Birmingham, West Midlands Regional Centre for Playwork Education and Training

Wood, A. (2006). "The new playwork national occupational standards - challenge or opportunity?" Playwords, Spring (28), 18-19. 